\title{
画像のスペクトルエンベロープ分析による車両巾計測
}

\author{
学生員 近藤 広 隆 (立命館大学) \\ 正員 中西 恒 彦 (立命館大学)
}

\section{Measurement of Vehicle Width by Analyzing Spectrum Envelope of Image}

Hirotaka Kondo, Student Member, Tsunehiko Nakanishi, Member (Ritsumeikan University)

This paper deals with a noncontact method to measure the width of vehicles by image processing.

There are many methods to measure the length of objects, but it is difficult to measure the length of moving objects without stopping. So a noncontact measurement method is needed for the vehicle width measurement. This paper reports the simple system construction using a portable camera and a personal computer, and reports calculating method using Fourier Transformation to achieve noncontact measurement of vehicle width.

We consider that the brightness of a vehicle on the image differs from background. The general measurement method is to count the pixels count or edge of difference in the brightness between a vehicle image and the background image, but the accuracy of this method is not high enough. We make a spatial frequency spectrum of the image for scale of measurement, which corresponds to vehicle width, and we reanalyze the frequency analysis of the brightness spectrum. Then, we are able to obtain the vehicle width.

In this paper, we show the usefulness of this method for the width measurement of vehicles in the traffic flow

\section{キーワード：非接触計測，画像計測，周波数分析，スペクトルエンベロープ}

\section{1.まえがき}

現在の自動車交通流において，大型車混入率が交通流特 性に影響を与え，洗滞等を引き起こしていることが知られ て扔り，その影響を予測し，適切な交通情報を流すことが 必要である，そのためには車両の走行速度や交通量に加え て車種判別の情報が重要となる，そこで，本報告では車種 判別に必要な車両大きさ，すなわち車両巾を画像のスベク トルエンベロープ分析から計測する方法について述べる。

現在使われている自動車の長さの計測方法は，超音波パ ルスの反射信号計数法や, 道路面に埋め込んだコイルのイ ンダクタンス変化計測法, 車両の走行ラインに沿って必要 な数の光電スイッチを配置した光ビーム切断式長さ計を用 いた計測法等がある ${ }^{[1]}$.しかし，これらの方法は，計測シ ステムの設置が大規模になる等の問題点が挙げられ，移動 物体の計測法として望ましい方法ではない，これらを解決 するための計測法として，画像計測による非接触計測法が ある。

画像計測による徒来からの一般的方法では，物体をC C Dカメラ等で撮影し，バックグラウンドとの明度差から
エッジを識別して，そのピクセル数を計数する方法である $か^{[2]}$, バックグラウンド明度の変動により闘值明度の設定 が困難となり，高精度の計測が期待できなかった。また， 移動物体の撮影にはブレを生し，エッジの検出が困難であ る、これらのエッジ検出法は微分演算と等価であり，明度 の不均一性や明度雑音などに対する不確実性の欠点を有し ている，本報告で提案する方法は空間周波数を計测尺度上 する方法で，バックグラウンドと物体の明度差が曖昧で あっても計測が可能となる，また，二度の積分演算による 計測であるためノイズに強い車両巾計測が行える特徴を有 している，一方で，画像計測では情報量が過大になり，リ アルタイム計測は困難とされているが，著者らは抽出情報 量を限定して高速化を実現する方法を提案しており ${ }^{[3][4]}$, 交通流計測に適用している。これは，可搬性に優れた沉用 ビデオカメラを用い, リアルタイム自動化計測の寒現のた めに, 眏像信号の一部分の明度情報のみを抽出する方法を 採っている，それにより，情報量が軽堿でき，パーソナル コンピュータや簡単なシステム構成で高速に情報処理が行 える.この方法により, 移動物体の長さが限定された場合 にはフレーム時間内での物体の存在検出を空間周波数分析 
によって可能にしている，本報告ではこの存在検出に加え て，車両巾の自動化計測法について提案する.

ここでは車両の明度分布が一定で，道路との明度差が存 在するものとし，映像から得られた物体の明度分布に対し て空間周波数分析を行う。計算されたパワースペクトルの エンベロープは周期性を持ち，この周期性が車両巾に対応 している.この周期性を捉えるために，再度の周波数分析 を行って車両巾計測を実現した，また，実画像計测を通し て本方法の精度について報告する。

\section{2. 画像と周波数スペクトル}

フレーム時間内リアルタイム計測を行うため，文献[3] [4]で述べているように車雨進行方向に対して直角に，す なわち道路断面方向に特定部分の明度分析頒域を設け，之 こで得られる明度分布から車両巾計測を行うことにした。

$\langle 2 \cdot 1\rangle$ 画像抽出法本方法では，必要な画 像情報は一部分のみとするので，画像全体を抽出する沉用 のフレームメモリボード等を用いるのは，リアルタイム計 測を行う上で不適当となる。 そこで，特定部分の明度分析 領域に対态した映像信号（NTS C信号）だけを直接サン プリングすることにした。この領域の抽出のために，パー ソナルコンピュータのグラフィック表示機能を利用し，グ ラフィック信号をN T S C 信号と同期をとって映像抽出の サンプリング制御信号に当てる.一方で，このグラフィッ ク信号とNTSC信号をスーパインポーザに通して重的合 わせた映像から，サンプリングポイントが容易に判断でき る. また，グラフィック信号のコントロールにより任意位 置設定が可能となる。これにより，リアルタイム画像抽出 が任意領域で実現できる。

$\langle 2 \cdot 2\rangle$ 明度パワースペクトル 上記の方法 によって得られる明度波形 $g(x)$ を(1) 式に示す。

$$
g(x)=\left\{\begin{array}{cc}
H+d & \left(|x-\tau|<\frac{W}{2}\right) \\
d & \left(|x-\tau|>\frac{W}{2}\right)
\end{array}\right.
$$

ただし， $d$ : 道路明度

$H:$ 車両と道路の明度差

$W:$ 車両巾

$\tau:$ 車両 $の$ 中央位置

$x$ : 分析領域の位置

この波形に対して空間周波数分析（フーリエ変換）を行う が，得られた明度分布の空間周波数スペクトルは車両位置 の影響を受けており，このスペクトルから車両巾の解析を 行うのは困難である。そこで，位粗の影響を打ち消すため に，そのパワーを求めると，明度分布のパワースペクトル $P_{o}(f)$ は,

$$
P_{o}(f)=\left\|\frac{H}{\pi f} \sin (\pi W f)\right\|^{2}
$$

となり，車両位置の影響を受けなくなる。なお， $f$ は明度 分布の周波数成分で, この結果の導出は文献[3]に明確に 示されている.

$\langle 2 \cdot 3\rangle$ 物体長の特徴量車両巾に依存した 明度分布パワースペクトルの周波数特性を（2）式に基づ いて作図したものが図 1である. 横軸は画像の空閒周波数 (cycle/m)で，綐軸㹥各周波数成分に対するパワーであり， 車両と道路の明度差に依存する。ここで，車両巾 $W_{1}$ は短い 巾の車両を想定し, 車両巾 $W_{2}$ は長い巾の車雨を想定して いる.この図のエンベローブにはパワーがゼロとなる極小 值が周期的に現れており，その周期は車両巾 $W$ に反映され ていることが示される。また，その周期は車両と道路の明 度差 $H$ の值に影響を受けないというのは（2）式からも明 らかである.したがって, この極小值の位置の計測, また はエンベロープの周期の推定によって，明度差に依存しな い車両门計測が実現できる。

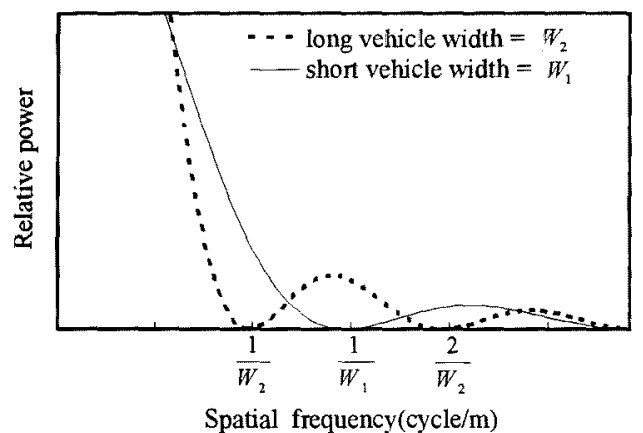

図1、車両の大きさによる明度分布パりースペクトル Fig.1. The power spectra of some vehicle models for width difference.

\section{3、エンベロープ周期による車両巾推定法}

図1の結果より，微分演算による極值解析を行い、極小 值が存在する周波数 $f$ を一点だけ求め, その周波数の值か ら車両巾を推定するのは可能である。しかし，一点の極小 值だけを捉えて車雨巾と判断するのは誤計測の可能性があ る，実際の映像はノイズの影響を受けており，必ずしも一 点の極小值が真の車雨巾を示しているとは言えない，そこ で，エンベロープ周期を推定する方法を試みた。このため， 明度分布パワースペクトルに対して再度の周波数分析を行 い, エンベロープの周期性分析を行った，図2 はこの周期 性分析をD F T (Discrete Fourier Transformation)によって 行った結果の一例で，車両巾を $1.5 \mathrm{~m}$ 想定した。 


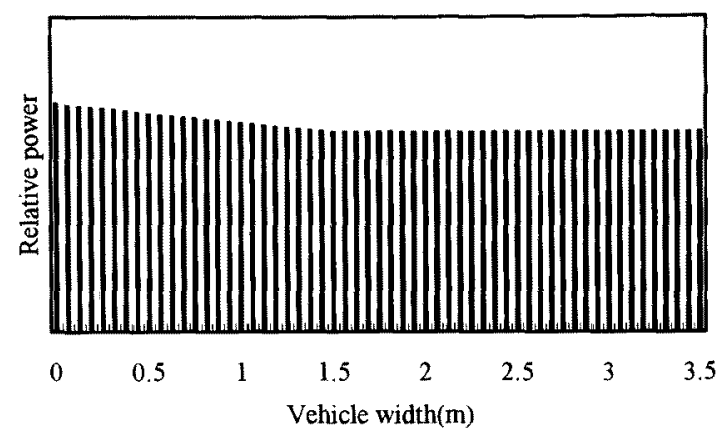

図 2. 明度分布パワースペクトルの周期性成分パワー

Fig.2. The periodic component of power spectrum.

この結果，パワースペクトルのエンベロープに対してそ のまま周期性分析を行っても，エンベロープの周期を捉之 られないことが示された。これは $f=0$ でパワー值がゼロ， 寸なわち極小值になっておらず，周期がくずれていること に起因している。ここで（2）式に着目すると，明度分布 のパワースペクトルは正弦関数と $1 / f$ 減衰関数の積の自乗 で与えられており， $f=0$ で極小值周期をくずしているの は， $1 / f$ 減衰関数に起因していると考えられる，そこで， この1/f特性を補正するために，明度分布パワースペクト ルに対して $f^{2}$ 倍の乗算を施す，その補正パワースペクト ルに対して，周期性分析である再度の周波数分析を行うこ とにした，補正パワースペクトル $P_{c}(f)$ は,

$$
\begin{aligned}
P_{c}(f) & =f^{2} \times P_{o}(f)=\left\|\frac{H}{\pi} \sin (\pi W f)\right\|^{2} \\
& =\frac{H^{2}}{2 \pi^{2}}(1-\cos (2 \pi W f))
\end{aligned}
$$

となり，当然，車両巾に対応した周期性を持っている。 方， $P_{c}(f)$ は偶関数であるから，周期性分析に際して，正 弦変換を行う必要がなく余弦変換のみの積分演算で十分で あり，高速な周期性分析が可能となる。このようにして得 られるエンベロープの周期性成分 $C(\alpha)$ は，

$$
\begin{aligned}
C(\alpha) & =\frac{1}{2 \pi \beta} \int_{0}^{2 \pi \beta} P_{c}(f) \cos (2 \pi \alpha f) d f \\
& =\left\{\begin{array}{cc}
H^{2} / 2 \pi^{2} & (\alpha=0) \\
-H^{2} / 4 \pi^{2} & (\alpha=W) \\
0 & (\alpha \neq 0, \alpha \neq W)
\end{array}\right.
\end{aligned}
$$

$$
\text { ただし, } \beta=1,2, \cdots
$$

となる.ここでいは補正パワースペクトルの周波数であり， エンベロープ周期, すなわち, 長さを示すディメンション となる，また， $2 \pi \beta$ は積分範囲を示している。

この結果，周期を示す $\alpha$ がゼ口の時と， $\alpha$ が車両巾 $W に$ 一致した時にのみスペクトルが存在することが示された。

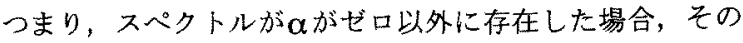

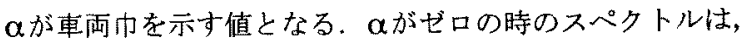
補正パワースペクトルの直流成分值を示している.

\section{4.ディジタル処理による車両巾計測}

$\langle 4 \cdot 1\rangle$ エンベロープ近似と計測範囲 3 章では，観測される明度波形を連続関数とし，分析領域長 が無限として扱ってきたが，実際には離散的なデータが得 られ，そのデータ数も限定される.このため，車両の存在 を想定した明度波形データに対してDF Tを施しても，パ ワースペクトルは離散的になり，スペクトル分解能が低下 する。これはサンプル区間に対応する明度分析領域の長さ が短いときには顕著になり，理論に示した明度分布のエン ベロープが捉えられない，また，明度分析領域の長さが長 く, 明確なエンベロープが得られたとしても，周期性分析 による測長可能な範囲は, 明度分析領域の長さの $1 / 2$ あ り，得られた長さが車両巾を示しているのか，車両の陰に なっていない部分の道路巾を示しているのかの判別は不可 能である。 そこで，仮想的に明度分析領域を搪大した。

道路の明度值と同じ值のデータを引き延ばすことで，仮 想的に分析領域を拉大寸ると，近似的に原型のエンベロー プを得ることができ，得られる長さの範囲も，仮想分析領 域に応して広くなり, 実際の分析領域の長さを分析可能に する，その仮想分析領域の長さは，少なくとも害際の分析 領域の長さの2 倍を必要とする。

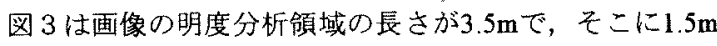
巾の車両が存在している場合を想定したときの明度分布パ ワースペクトルと，その補正パワースペクトルをD F Tに よって求めた結果である。ここでは，分析領域巾を 4 倍に 桩大して分解能を向上させている.

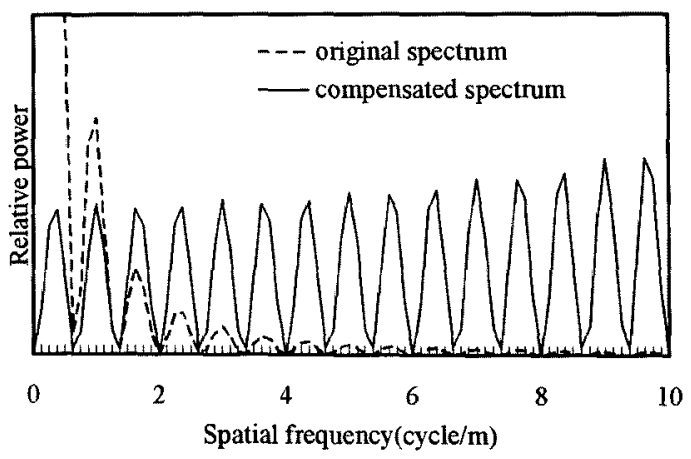

図 3、車両明度分布データに対するパワースペクトル

Fig.3. The compensated power spectrum of model vehicle.

補正スペクトルのエンベロープは実線で示しているが， この方法によって得られるエンベロープは，ほぼ正規の積 分計算で得られる余弦曲線に近い形が得られることが示さ れ，周期も明確に現れる，なお，引き延ばしデー夕数をよ り多く増やせば，パワースペクトルのエンベロープ周期が， より明確に現れる。 
$\langle 4 \cdot 2\rangle$ 車両巾計測 図3の補正エンベロープ から車両巾を求めるための周期性分析，すなわち，DC T (Discrete Cosine Transformation) を実施したスペクトルを 図4に示す. なお, パワーの標本データ数はエイリアシン グを考慮に入れて, 明度分布標本データ数の $1 / 2$ であり, そのデータ数で D C Tを施し，そのパワーをとっている ${ }^{[5]}$. 具体的には, 明度分析領域から得られる画像分析標本デー 夕数は64点で, 仮想的に明度分析領域を広げるために, 64 点目を256点目まで引き延ばして得たパワースペクトルに 対してDCTを施している.

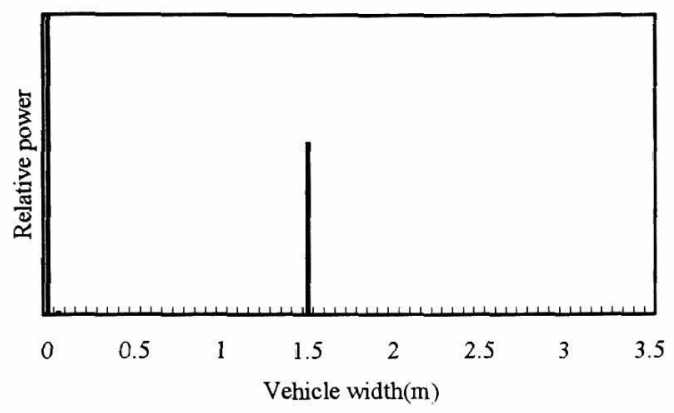

図 4. 補正パワースペクトルに対する 周期性成分パワー

Fig.4. The periodic component power of compensated power spectrum.

このようにデータを引き延ばし, 仮想的に明度分析領域 を広げることによって得られたスペクトルは, 単一スペク トルとはなっていないが，周期がゼロ付近を除いてパワー 值が最大となったときの周期が物体長を示しており, 確実 に明度分布パワースペクトルのエンベロープ周期を捉える ことができた．この図では、車両巾以外の周期スペクトル がほとんど現れていないが，実際には小さいパワー值を 持った周期スペクトルが極わずか出ている. また，画像分 析標本デー夕数が少なければ, 車両巾以外を示寸周期スペ クトルが現れるが，車両巾に対応するスペクトルが大きく 現れている.

$\langle 4 \cdot 3\rangle$ 計測精度とデータ数 仮想明度分析 領域の長さを $(5)$ 式で示すと, 明度分布 $g(x)$ の空間周 波数 $f$ は $(6)$ 式となり, 離散的な值を取る.

$$
\begin{aligned}
& L_{\mathrm{i}}=L_{\mathrm{o}} \frac{N_{i}}{N_{o}} \\
& f=\frac{n}{L_{i}} \\
& \text { ただし, } \\
& N_{o}: \text { 画像分析標本データ数 } \\
& N_{i}: \text { 仮想明度分析標本データ数 } \\
& L_{o}: \text { 画像分析領域の長さ } \\
& L_{i}: \text { 仮想明度分析領域の長さ } \\
& n \text { : 高調波次数 }(n=0,1,2, \cdots)
\end{aligned}
$$

また，エンベロープ周期分析範囲の有効最大值 $f_{\text {max }}$ は $n$ の
最大值を $N_{i} / 2$ として，

$$
f_{\max }=\frac{N_{i}}{2 L_{i}}
$$

である。この範囲で周期性分析を行うときの分解能は $1 / f_{\text {max }}$ で, 周期に対応する $\alpha$ は分解能と高調波次数 $m$ の積 で,

$$
\alpha=\frac{m}{f_{\max }}=m \frac{2 L_{i}}{N_{i}}=2 \frac{n L_{o}}{N_{o}}
$$

$$
\text { ただし, } m: \text { 高調波次数 }(m=0,1,2, \cdots)
$$

と与えられる。つまり，仮想明度分析領域の長さは周期分 析精度に影響を与えず， $L_{o} / N_{o}$ ，すなわち，ピクセルサ イズに分析精度は依存することになる．また，エンベロー プ周期分析範囲を小さくると，それに応じて分解能が低 下し，分析精度が落ちることになる．ちなみに周期分析の ための有効デー夕数 $m$ は周波数データ数の $1 / 2$ であって, $m=N_{i} / 4$ となり, 测長可能な最大長さ $\alpha_{\text {max }}$ は

$$
\alpha_{\max }=\frac{L_{i}}{2}
$$

である.

\section{5. 実画像計測}

スペクトルエンベロープの分析法による車両巾計測を実 画像において試みた。計測法の概要は, 高所に設けたビデ オカメラで道路を撮影し, 明度分析領域を道路断面方向に 設け，そこで得られる明度データから車両巾計測を行うこ とにした．ただし，計測するにあたってその明度分析領域 内の道路幅をあらかじめ計測しておく必要がある.

今次の実験では1994年10月15日昼間に, 滋賀県草津市内 京滋バイパス歩道橋上にカメラを設置し, 自動車交通流の 撮影を行った。図 5 は自動車交通流の実写映像と明度分析 領域（線分）を示す.

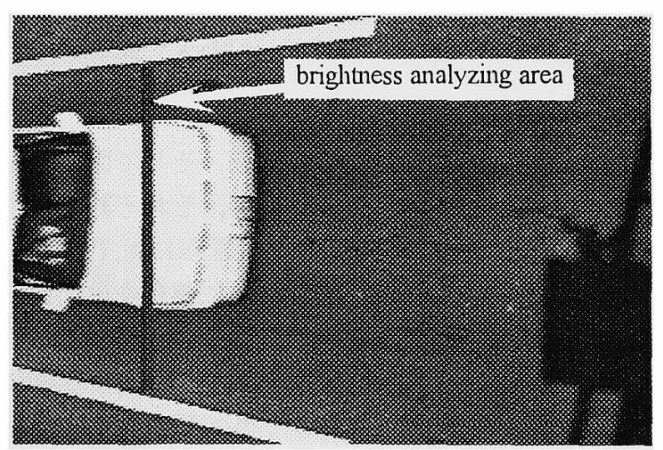

図 5. 実写映像と明度分析領域

Fig.5. An example of camera location and brightness analyzing area. 


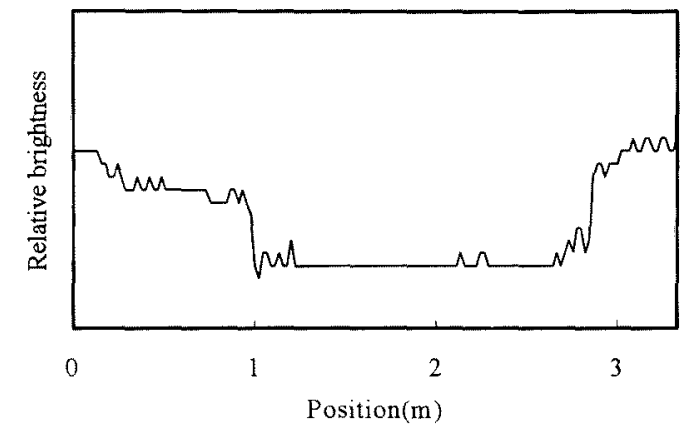

(a) 明度分布

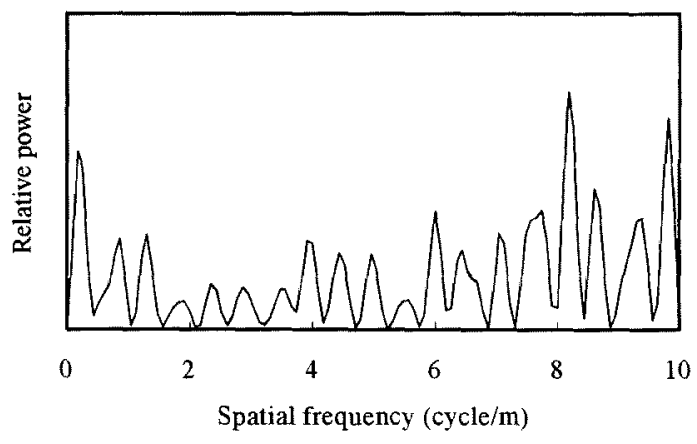

(b) 明度分布の補正パワースペクトル

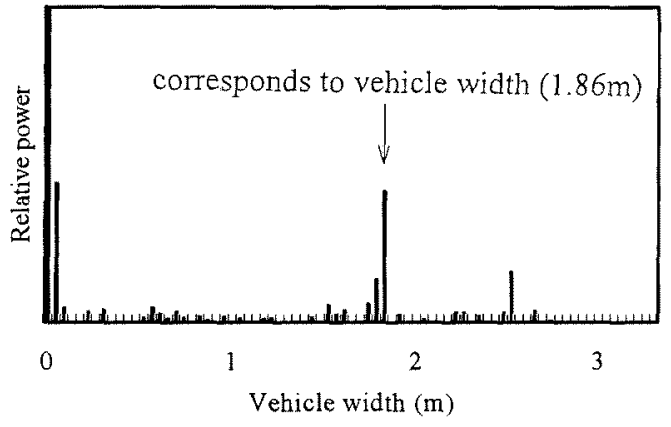

(c) 補正パワースペクトルの周期性成分パワー

図6。黒い車両に対寸る周波数分析

Fig.6. The frequency analysis of black vehicle

図 6 は車両巾 $1.86 \mathrm{~m}$ 黑い車両の例，そして図 7 は車両 巾 $1.76 \mathrm{~m} の$ 中間色の車両の例について，それぞれ得られた 明度分布と補正パワースペクトル，さらにはそのエンベ ロープ周期性成分を示している，一般に黒色や中閐色の車 両のスペクトルは不明確となるが，実画像計測においいても， 明度分布パワースペクトルのエンベロープ周期は明確に現 れており，その補正パワースペクトルの周期性スペクトル が最大值となったときの周期の值が，その車雨巾を示して いる。な⿰扌，白色車両のスペクトルは図 $3 \sim 4$ とほほ同様 になる。

今次実験の車雨巾計測では走行する車両に対して順次周

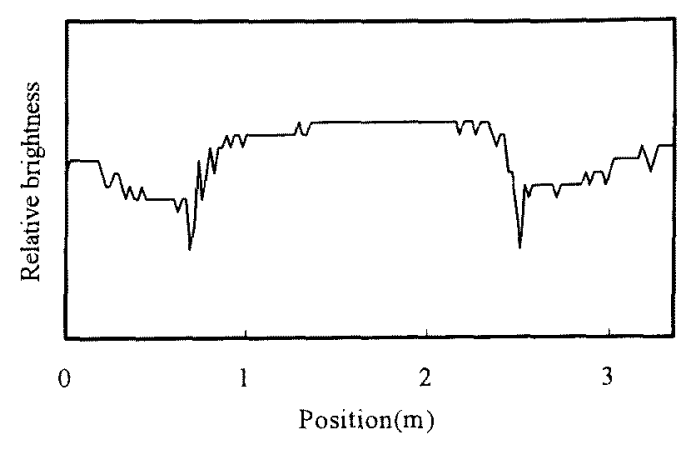

(a) 明度分布

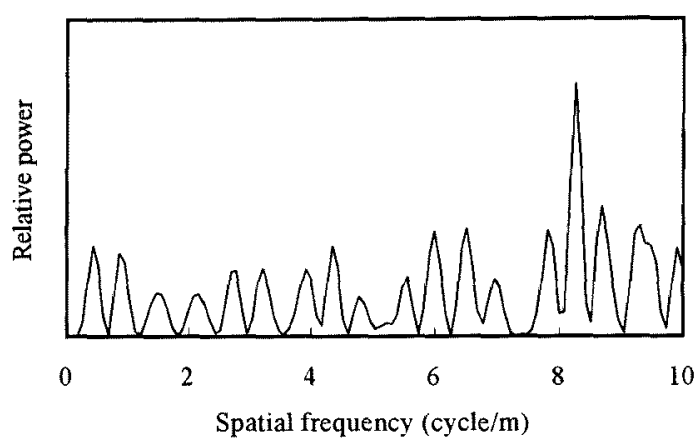

(b) 明度分布の補正パロースペクトル

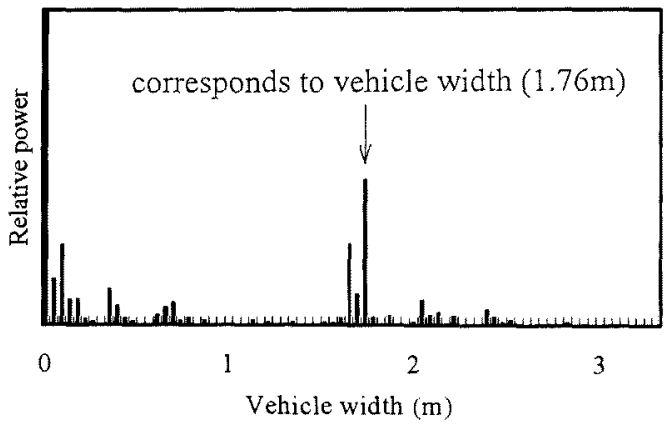

(c) 補正パワースペクトルの周期性成分パワー

図 7.中間色の車両に対する周波数分析

Fig.7. The frequency analysis of gray vehicle.

期性パワースペクトルを計算し，1３mの範囲で最大パ ワーを有する周期を求めた。図 8 には実測車両巾と計測車 両巾の関倸, 表 1 にはその色別の計測精度を示している。 これらは走行車150台について計測した結果であり，その 内訳は白い車両が 69 台，黒い車両が51台，中間色の車両 が30台である。なお，これらの計測は画像分析領城を道 路上の $3.34 \mathrm{~m}$ とし，この長さは画像上で150ピクセルに対 応している，この150点をF F Tが使用可能となる512点 までデー夕を引き延ばし，分解能が最大となるエンベロー プ周期分析範囲の有効最大值 $f_{\max }$ まで周期性分析を行い, 車雨巾計測を行った。 
図8から，車両巾による計測精度に違いが生じないこと が示されている. また表 1より，中間色の車両巾計測の精 度には白い車両や黑い車両と比べてばらつきが生じ, 誤差 の值も大きくなっていることが示されている，実際の映像 では，輬跡などの影響で道路明度は一定ではなく，明度が 勾配を持った值となっており, 中間色の車両の計測精度が 落ちるのは道路の明度分布に影響を受けやすいことに起因 している.また今次実験において, 計測を行った車両の走 行速度は様々であり, 道路上の走行位置も様々であった。 しかし，パワースペクトルを評価対象に選んだことで走行 位置による計測精度に違いは見られなかった。 また単一フ レームの画像分析であるので走行速度による影響もなく， 全車両における計測誤差は $5 \%$ 以内であった。 なお, 車両 巾が 1 ピクセルずれた場合，このスペクトルエンベロープ の周期が約 $4.5 \mathrm{~cm}$ 変化する.すなわち今次計測では，その 誤差はスペクトル分解能によって生じる誤差範囲内にほと んどが含まれている結果といえ, 最大でも 2 ピクセルのず れに納まっている. 以上のことから本計測法は車両㠹測 を行ううえで十分適用できる結果だといえる.

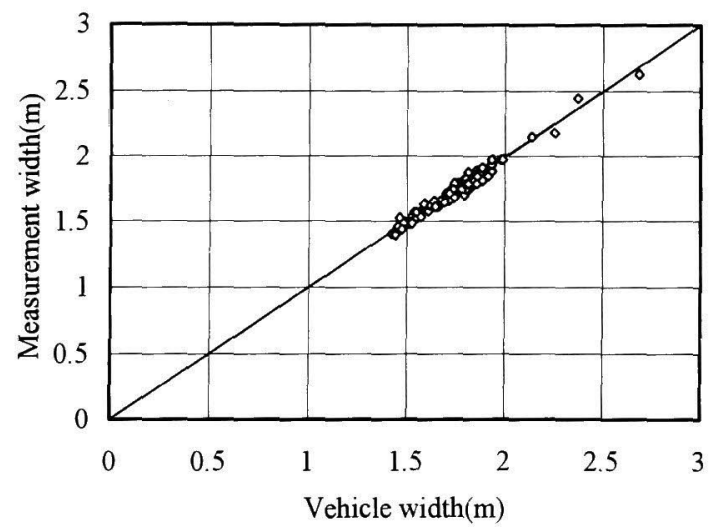

図 8. 計測結果

Fig.8. The result of measurement

表 1 . 計測精度

Table 1 . The accuracy of measurement.

\begin{tabular}{c|c|c}
\hline & $\begin{array}{c}\text { maximum } \\
\text { error (\%) }\end{array}$ & $\begin{array}{c}\text { average } \\
\text { error (\%) }\end{array}$ \\
\hline WHITE VEHICLE & 3.78 & -0.54 \\
\hline GRAY VEHICLE & 4.88 & -1.30 \\
\hline BLACK VEHICLE & 3.78 & -0.67 \\
\hline
\end{tabular}

\section{6. あとがき}

本論文では計測対象を自動車交通流とし，その車両巾計 測の非接触計測実現のため，画像計測での手法について述 ぐた. その精度は画像分析標本データ数に応じて変動する
が, 標本化誤差, スペクトル分解能による誤差内でほぼ車 両巾計測が行えることを示した。より高精度に計測したい 場合には，より多くのデータをサンプルする必要がある． しかし, 得られるデータ数には限りがあり, 画像の解像度 に問題もあるので, 画像計測での精密計測は限界がある. それでも本方法において, 車両巾の非接触自動化計測を実 現する可能性を見出すことができた．また，今次は車両を 計測対象にしてきたが, 車両に限らず明度分布一定の物体 に対しても比較対象の長さが確認できたなら, 非接触に物 体長計測を行う可能性も見出すことができた.

(平成 7 年 1 月 27 日受付, 同 7 年 5 月 17 日再受付)

\section{文 献}

[1]宮迫康夫, 宮内 勝:「車両センサーの研究開発状況」, 交通工学, Vol.20,No.4,pp.45-50(1985)

[2] テレビジョン学会:「テレビジョン画像工学ハンドブッ ク」,オーム社, pp. 1245-1249(1984)

[3] 田口耕造, 小野川義彦, 中西恒彦：「T V 映像加らの車 両認識」, システム制御情報学会論文誌, Vol.6,No.10,pp 446-456(1993)

［4］吉川仲次, 田口耕造, 中西恒彦：「T V 画像による交通 流計測」, 電学論 C, 114巻 11 号, 平成 6 年, pp.1154-1159

[5]佐川雅彦, 貴家仁志：「高速フーリエ変換とその応用」 昭晃堂, (1992)

［6］近藤広隆, 中西恒彦：「画像を用いた物体長の計測」， 平成 6 年電気関倸学会関西支部連合大会講演論文集, p.G60(1994)

[7] 前田 渡：「ディジタル信号処理の基礎」,オーム社, (1980)

近藤 広隆 (学生員) 1972年 3 月25日生まれ。平成 6

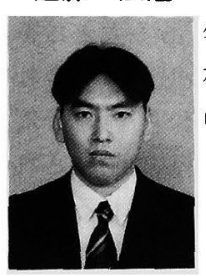
年立命館大学理工学部電気工学科卒業. 現 在同大学大学院理工学研究科修士課程在学 中. 画像計測に関する研究に従事.

中西 恒彦（正員）1944年 1 月 1 日生まれ．昭和43年

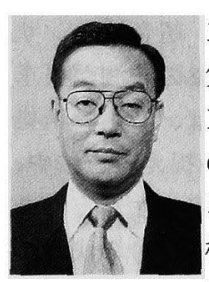
立命館大学大学院理工学研究科修士課程電 気工学専攻修了．立命館大学理工学部電気 工学助手を経て現在同教授．放射能計測器 の開発から計測工学に入門し，現在ではラ ンダム現象である自動車交通流の計測と解 析法の研究に従事. 工学博士. 電気学会, 計測自動制御学会, 交通工学研究会などの 会員 